\title{
Presence of Salmonellaspp from Oreochromis niloticus (Tilapia) Sold in Ibadan, Nigeria
}

\author{
Olayinka Olabisi Ishola*, Seto Charles Ogunleye, Olayemi Akinsola Okunlade, Olufemi Bolarinwa Adedeji \\ Department of Veterinary Public Health and Preventive Medicine University of Ibadan, Ibadan, Nigeria \\ *Corresponding Author \\ DOI: https://dx.doi.org/10.51584/IJRIAS.2021.6403
}

\begin{abstract}
Salmonella spp. are classified as part of the nonindigenous bacteria of fish. They play an important role in fish spoilage, and causing foodborne diseases in humans manifested as enteric fever, bacteremia, gastroenteritis and/or death. Majority of 1.3 billion annual cases of salmonella cause human gastroenteritis resulting from ingestion of contaminated food products. Salmonella isolation from food materials and its resistance to antibiotics are of great global public health concerns. This study therefore investigated the prevalence and antibiogram of Salmonella spp.from $O$. niloticus sold in Ibadan. A total number of 156 samples consisting of gills $(n=52)$, intestines $(n=52)$ and skins $(n=52)$ were collected from $52 O$. niloticus from Egbeda, Ido, Ibadan North-East and Ibadan North-West Local Government Areas (LGA) for bacteriological analysis. Salmonella isolation and identification were performed using ISO 6579, 2017 standard methods and antibiogram was performed with agar disk diffusion method. Data were analysed using ANOVA and students $t$-test at $p \& I t=0.05$. Overall prevalence of Salmonella of $12.5 \%$ was obtained (Gill= $8.3 \%$; Intestine $=\mathbf{4 . 2} \%$ and $\mathrm{Skin}=\mathbf{0 . 0} \%$ ). Isolates exhibited multidrug resistance patterns comprising: $100.0 \%$ (Ceftazidime, Cefuroxime and Meropenem), 91.7\% (Cefotaxime), $83.3 \%$ (Tetracycline), $50.0 \%$ (Cotrimoxazole), $33.3 \%$ (Ceftriaxone and Gentamycin), $25.0 \%$ (Chloramphenicol), 16.7\% (Amikacin) and 8.3\% (Ciprofloxacin). The prevalence of Salmonella sppin 0. niloticus sold to Ibadan populace indicates high levels of contamination and portends public health risks. High resistance of the pathogen to antibiotics signifies abuse and indiscriminate disposal of antibiotics and possible transmission of resistant genes to fish consumers.
\end{abstract}

Keywords: Salmonella, Antibiogram, and Oreochromis niloticus.

\section{INTRODUCTION}

A quaculture has been known as the fastest growing source of protein production for human consumption worldwide $[1,2]$ whilst Oreochromis niloticus has been identified as the most cultured fish around the world [3]. Theproduction and consumption of fish in Nigeria has been a major source of animal protein competing favourably with meat. Tilapia belongs to Cichlidae family of ray-finned fish, characterized by a single nostril on each side of the head, an interrupted lateral line, and lack of subocular shelf [4]. They inhabit a variety of water habitats [4] and true tilapias are native only to Africa and the Middle East $[5,6]$. It is widely accepted in most parts of the country because of its unique taste, flavor and good texture. Tilapia is characteristically accepted worldwide for low saturated fat, calories, carbohydrates, and sodium contents, good protein source with micronutrients such as phosphorus, niacin, selenium, vitamin B12, and potassium [7, 8]. Despite the importance of tilapia as a source of high digestible proteins, they also serve as a source of food-borne toxinfections to human [9] through the consumption of contaminated fish and fish products. Howbeit microbial flora associated with freshly harvested fish is principally function of the environment in which they are caught, their indigenous microbial populations can vary significantly $[10,11,12]$.

Bacteria associated with fish are classified into nonindigenous and indigenous bacteria. The non- indigenous bacteria include Clostridium botulinum, Salmonella spp, Listeria monocytogenes, Staphylococcus aureus, Shigella spp. and Escherichia coli. The indigenous bacteria include Vibrio spp., Vibrio parahaemolyticus, Aeromonas, and Yersinia [13]. Salmonella spp,one of the most important non-indigenous bacteria a facultative anaerobic, and oxidase-negative, usually mobile, that produces gas from glucose. Its growth temperature ranges from $7^{\circ} \mathrm{C}$ to $46^{\circ} \mathrm{C}$; growth $\mathrm{pH}$ ranging from 3.8 to 9.5 ; minimum water activity for growth is 0.84 and optimum salt concentration is up to $4 \%[12,14]$. Salmonella is not pathogenic bacteria of fish, therefore, are not naturally found on them.Its occurrence is commonly related to fish breeding, industrialization environment, inefficient hygiene practices, unhygienic equipment, and food handling $[12,15]$.Often, fish contamination occursthrough contaminated water or improper handling $[12,16]$.

Salmonellosisresulting from fish consumption has become a global public health concerns[17]. This can be associated with the significant increase in consumption of aquaculture products, especially raw products, which increase pathogen exposure risks, especially in vulnerable groups (pregnant women and infants)[17, 18]. Infections due to Salmonella cause about 1.35 million infections; 26,500 hospitalizations, and 420 deaths in the United States annually most of these cases are traced back to food [19]. Salmonella is 1 of the 4 key global causes of diarrhoeal diseases [20]. Salmonellosis is characterized by a wide range of human diseases such as; acute onset of fever, abdominal pain, diarrhoea, nausea and vomiting.Several studies have demonstrated the isolation with different prevalence of Salmonella in different species of fish ranging between $2.7 \%$ to as high as $64 \%[13,21,22]$.Microbiological standards for fish processing and marketing for ensuring absence 
of Salmonella in foods in compliance with World Health Organization (WHO) are therefore integral recommendations.

The use of antibiotics is reserved for patients with serious diseases or at high risk of invasive diseases [23]. Antibiotic therapy scheme for typhoid fever includes the third generation cephalosporin antibiotics, quinolones and macrolides. However, lately, there have been resistance developments between typhoid Salmonellas and non-typhoid strains with high levels of resistance to quinolones and cephalosporin [24].Antimicrobial Resistance (AMR) and the emergence of Multiple Drug Resistant to Salmonella (MDR) has become global public health concernrepresenting an increase in the severity of foodborne disease, leading to increased hospitalization rates and possibility of death [25]. Understanding the main risk factors and how to reduce them is therefore essential for developing best management practice to safeguard public health. This present global issues therefore, necessitated this study to determine the occurrence and antibiogramof Salmonella species isolated fromO. niloticus collected from fish farms in Ibadan, Nigeria.

\section{MATERIALS AND METHODS}

\subsection{Sampling Method and Sample Collection}

This cross-sectional study involved fish farms raising Tilapia in four Local Government Area (LGA) of Ibadan, Oyo State, Nigeria. Egbeda (A), Ibadan North West (B), Ido (C), Ibadan North East (D) LGAs in Ibadan were purposively selected based on the availability of fish farms cultivating Oreochromis niloticus. Four farms comprising two feral (1 and 2) from A and B LGAs and two cultured farms (3 and 4) from $\mathrm{C}$ and D LGAs were purposively selected for sample collection. A total of fifty two (52) apparently healthy, tablesized (average weight $120 \mathrm{gm}$ ) live tilapia comprising 16 each from the feral farms (1 and 2) and 10 each from cultured farms (3 and 4) were collected between July and August 2019. Sampled tilapia were transported to the Food and Milk Hygiene Laboratory of the Department of Veterinary Public Health and Preventive Medicine, University of Ibadan for bacteriological analysis. On arrival at the laboratory, fish were stored briefly and were properly identified and organs of interest were aseptically harvested using scalpel. One gram (1gm) each of samples of gills, intestine and skin were collected and aseptically macerated separately with buffered peptone water (LabM®, UK). A total of 156 samples consisting of gills $(n=52)$, intestines $(n=52)$ and skins $(n=52)$ was therefore obtained from the 52 Oreochromis niloticus for bacteriological analysis. Samples were processed according to the protocols recommended by microbiological Standards and Guidelines by International Organization for Standardization (ISO 6579, 2017) and National Committee for Clinical Laboratory Standards (NCCLS, 2003).

\subsection{Isolation and Identification of Salmonella spp}

Isolation of Salmonella sppwas carried out according to the International Organization for Standardization (ISO
6579 , 2017) for isolation and characterisation of Enterobactereaca. Non-selective pre-enrichment was performed by aseptically harvesting $1 \mathrm{gm}$ of tissue sample, and then homogenised in $9 \mathrm{mls}$ buffered peptone water $(\mathrm{LabM} \AA$, UK) in a test-tube to give a dilution of $1: 10$. Test-tubes were corked properly, labeled and incubated overnight at $37^{\circ} \mathrm{C}$. 0.1 $\mathrm{ml}$ of the pre-enrichment inoculated into RappaportVassiliadis (RV) (Oxoid ${ }^{\circledR}$, England) for selective enrichment and incubated overnight at $37^{\circ} \mathrm{C}$. Selective agar plating was performed by plating $10 \mu \mathrm{l}$ onto Xylose Lysine Deoxycholate(XLD) agar $\left(\mathrm{Oxoid}^{\circledR}\right.$ ), and incubated at $37^{\circ} \mathrm{C}$ overnight. Suspected colonies which show small transparent black centers to predominantly black colonies were sub-cultivated unto Xylose Lysine Deoxycholate-(XLD) $\left(\right.$ Oxoid $\left.^{\mathbb{R}}\right)$ and incubated overnight (18-24 hours) at $37^{\circ} \mathrm{C}$ for Subcultivation/purification. This was followed by storage of pure cultures onto nutrient agar slants, incubated at $37^{\circ} \mathrm{c}$ overnight and stored in the fridge at $2^{0} \mathrm{C}-8^{0} \mathrm{C}$

\subsection{Morphological and Biochemical Tests}

Morphological characteristics of isolates were
performed through Gram staining. Biochemical characterization of isolates was performed by using sugar fermentation tests, Catalase, Indole and TSI. Incubate at $37^{\circ} \mathrm{C}$ overnight.

\subsection{Antibiotic Susceptibility Test}

The antimicrobial susceptibility test was carried out using the agar disk diffusion method as described by Bauer et al. (1966) and Clinical and Laboratory Standards Institute (CLSI) 2017 was used. Antibiotic sensitivity pattern of isolated Salmonella was performed against 12 commonly used antibiotics belonging to different groups using commercially available antibiotic discs (Biomark Lab ${ }^{\circledR}$ ) containing antibiotics at different micrograms. Amikacin (AMK, 30 $\mu \mathrm{g}$ ), Cefotaxime (CTX, 30 $\mu \mathrm{g})$, Ceftazidime (CPZ, 30 $\mu \mathrm{g}$, Ceftriaxone (CTR, 30 $\mu \mathrm{g}$ ), Cefuroxime (CRX, 30 $\mu \mathrm{g}$ ), Chloramphenicol (CHL, 10 $\mu \mathrm{g}$ ), Ciprofloxacin (CIP, 5 $\mu \mathrm{g}$ ), Cotrimoxazole (COT, 25 $\mu \mathrm{g}$ ), Gentamicin (GEN, 10 $\mu \mathrm{g}$ ), Meropenem (MEM,10 $\mu \mathrm{g}$ ), Tetracycline (TET, 10 $\mu \mathrm{g}$ ), Vancomycin (VAN, 30 $\mu \mathrm{g}$ ) were used to determine sensitivity and resistance patterns.

After 24 hours of incubation, inoculated plateswere examined. Diameters of the zones of inhibition were measured to the nearest millimetre, using ruler, which was held on the back of the inverted Petri plate. The Petri plate was held a few inches above a black, non-reflecting background and zones are measured in millimetre $(\mathrm{mm})$ from the upper surface of the agar illuminated with reflected light, with the cover removed (EUCAST, 2015).

\subsection{Data analysis}

Data were analysed using descriptive statistics and Chi-Square to test association between variables. 


\subsection{Ethical Approval}

The Animal Care and Use Research Ethics (ACUREC), University of Ibadan, Nigeria approved the study with approval number: UI-ACUREC/19/0079. Collection of samples was from consenting farmers raising tilapia fish and such farms were included in this study.

\section{RESULTS}

\subsection{Detection of Salmonella spp}

From the one-hundred and fiftysix (156) samples consisting 52 each of gills, intestines and skins collected from the 52 Oreochromis niloticus, Salmonella was detected from a total of twenty (20) samples. This represents an overall prevalence of $12.5 \%$. The positive samples comprising Thirteen (13) Gills and Seven (7) intestines representing 8.3\% and $4.2 \%$, respectively.

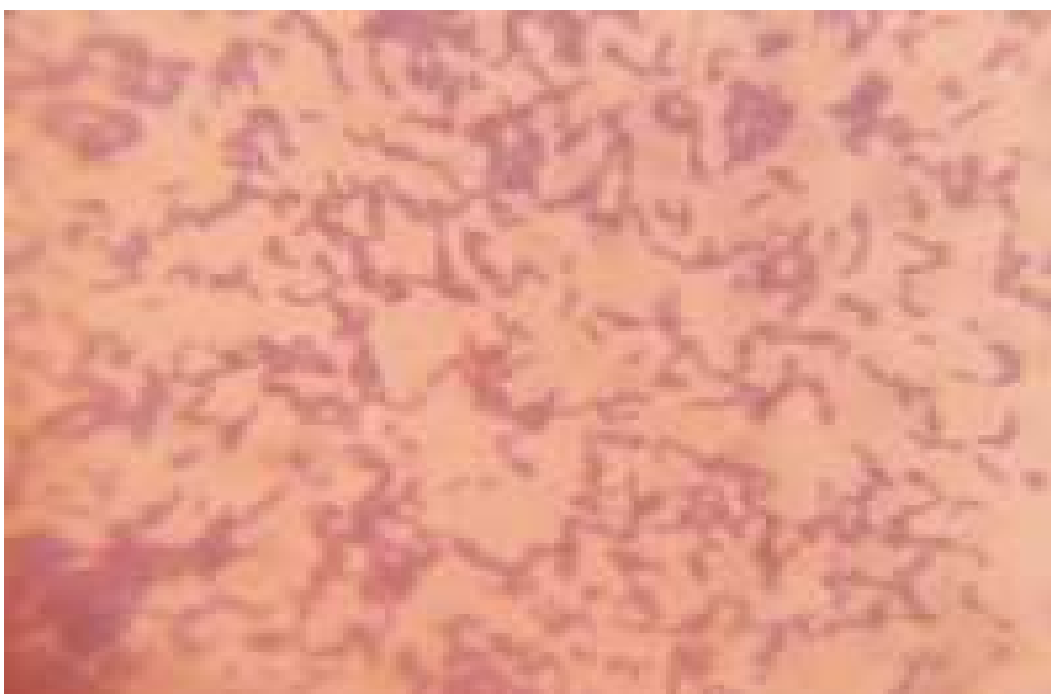

Fig 1.Salmonellaspp as Gram negative rods arranged singly and in clusters

\subsection{Antibiogram of Salmonella spp}

The Salmonella isolates showed highest resistance $(100 \%)$ to Ceftazidime (CPZ), Cefuroxime (CRX) and Meropenem (MEM) and highest susceptibility to
Ciprofloxacin (83.3\%) (fig 1). Different levels of Multi-Drug Resistance (MDR) patterns were observed with $100 \%$ to combination of CRX, CPZ, and MEM and least MDR of $25 \%$ to CRX-CTR-CTX-CFZ-MEM-TET-CHL (fig 2).

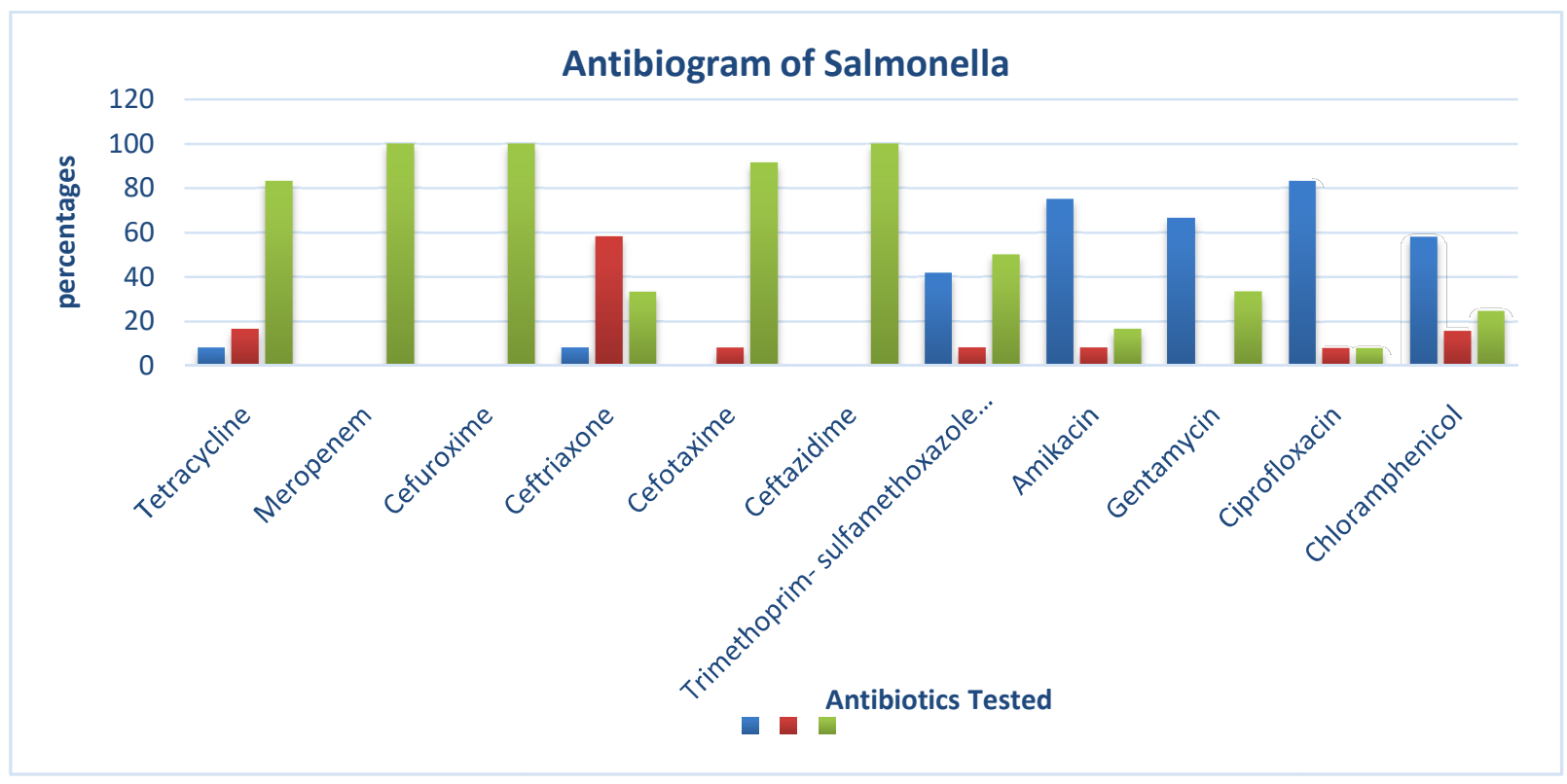

Fig. 1: The antibiogram distribution of Salmonella sppto the tested commonly used antibiotics 


\section{Multil-Drug Resistance Patterns of Isolated Salmonella spp (\%)}

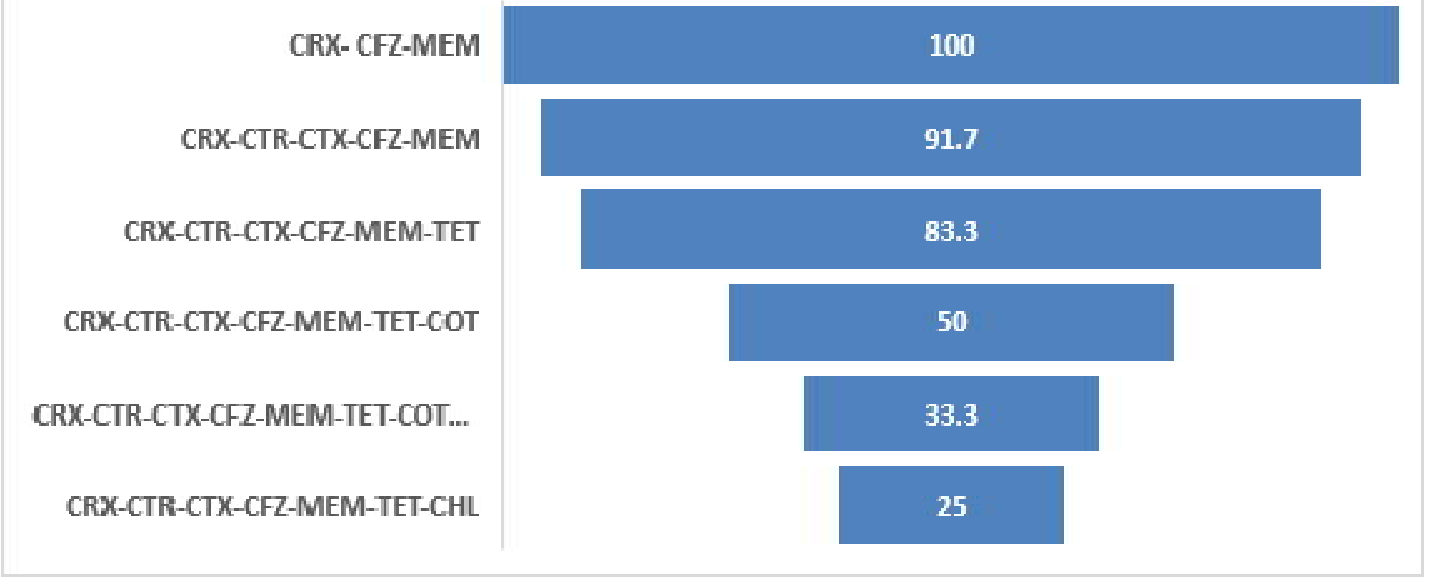

Fig. 2: The multi-drug resistance pattern of Salmonella sppto the tested commonly used antibiotics

\section{DISCUSSION}

Isolation of Salmonella from O. niloticus (tilapia) has been attributed to high levels of aquatic ecosystems' contamination by human activities. The observed prevalence of $12.5 \%$ for Salmonella is similar to the reports by Tiamiyuet al., 2011, Adebayo-Tayoet al., 2012 and Danbaet al., 2014 $[26,27,28]$ who all reported prevalence of Salmonella in tilapia fish ranging between $6-16 \%$. This observed prevalence however contrasts reports of Shinkafi, et al., 2010 [29] who reported a lower prevalence $(3.5 \%)$ in Sokoto State, Nigeria and the report of Seelet al., 2016 [30] who reported a higher prevalence $(75.0 \%)$ in Bangladesh. The isolation of Salmonella from the sampled fish in this study strongly suggests a high level of aquatic ecosystems contamination by human activities that further reinforces the observed contaminated environment and the human activities at the sampling locations, these are similar to the observations of Danbaet al., 2014 [28] and Fuhrimannet al., 2015 [31].The isolation of these pathogens from fish samples is worrisome because of their potential in causing ill-health in human. It is noteworthy to assume that these pathogens might have been introduced into the production process through human unhygienic activities, industrialization and continual waste disposal into water bodies as observed during sample collection in this study.Fish is an important source of animal protein for human diet, however, they are susceptible to a wide variety of bacterial pathogen. Many of these bacteria are capable of causing human infection and intoxication. The microbiological hazard of Salmonella contamination of fish and fish products during production in the aquatics, harvesting, storage and improper handling or cooking of fish can lead to human food-borne illness. Hence, there is need to monitor the contamination levels of Salmonella as well as other zoonotic pathogens to safeguard public health [30].

Salmonella isolates obtained from $O$. niloticus (tilapia) in this study were found to be sensitive to Amikacin, Ciprofloxacin, Chloramphenicol and Gentamicin and but showed $100.0 \%$ resistance to: Ceftazidime, Meropenem and Cefuroxime and high resistance (above 50.0\%) against Cefotaxime, Tetracyclin, and Cotrimoxazole. These observations contrasts the reports of Adedeji et al., 2011, Efuntoyeet al., 2012; Tiamiyuet al.,2015 andSeelet al., 2016 $[26,30,32,33]$ who reported resistance of Salmonella against both Tetracycline and Ciprofloxacin. There is however an observed similar susceptibility profile of Salmonella against Gentamicin and Chloramphenicol withAdedeji et al., 2011, Efuntoyeet al., 2012; Tiamiyuet al., 2015 and Seelet al, 2016.The relatively high level of resistance to antimicrobial agents could be a reflection of misuse or abuse of these agents in aquaculture and/or disposal to water bodies[34]. Concurrently, the isolates showed multiple antimicrobialresistances (Multi Drug Resistance- MDR pattern)against three to eight antibiotics, especially, to those antibiotics commonly used in fish farms such as Cotrimoxazole and Tetracycline. This result therefore, further provides evidence of Salmonella spp as multi resistant strain in nature, representing a potential threat to human health.These observations from this study are similar and affirm the reports of Adedeji et al., 2011; Rafael et al., $2014[32,35]$ who reported that ciprofloxacin, gentamicin and chloramphenicol were effective in controlling Salmonella sppinfection.MDR is a global public health problem and are associated with outbreak of major epidemics globally [25]. High resistance to antimicrobial agents is a reflection of their misuse or abuse in environment. This report therefore confirmed microbial resistance of Salmonella evidencing transfer risks of resistant bacteria to human through consumption of contaminated aquaculture products [36].

Antibiotic resistance and MDR are increasing rapidly, and developing countries are the worse affected; since they provide conditions and practices that support the development and spread of resistant microbes. Two theories have been advanced to explain the emergence of resistance in wild waters, i.e. resistant bacteria contaminating water from 
human or livestock sources; or antibiotic residues escaping into the water exposing the resident bacteria to low levels of antimicrobial agents overtime [36]. Transfer of antimicrobial resistant bacteria to wild water due to sewage contamination has been reported in Australia [36, 37]. The resisted antibiotics are those commonly used for treatment of various ailments in humans, thus strongly supporting the theories of introduction into the aquatic ecosystems from human associated sources.

\section{CONCLUSION AND RECOMMENDATIONS}

This study confirms the extent of Salmonella contamination, as well as the susceptibility and resistance characteristics of isolated Salmonella spp from Tilapia sold in Ibadan indicating that Tilapia harbour and could serve as a source of infectionfor human fish consumers and handlers.

The outcomes from this study therefore suggest that a comprehensive epidemiological study of Salmonella spp in aquatic production and value chain in Nigeria is germane towards monitoring the contamination levels zoonotic pathogens as well as controlling and preventive measure institutions. Further studies are required to understand and characterize Salmonella spp strain found in this study is also highly recommended. Furthermore, research and studies of aquatic animal health and zoonosis should be a focus to controlling diseases of public health importance.The public should be enlightened danger accompany handling and/or consumption of fresh and undercooked fish; sanitary conditions following standard practices should be improved.

\section{ACKNOWLEDGMENT}

We wish to appreciate all the participants involved in this study, Dr G.O Oladosu and Fish farmers, and the department of Department of Veterinary Public Health and Preventive Medicine University of Ibadan, Nigeria.

\section{CONFLICTS OF INTEREST}

Authors have no conflict of interest.

\section{AUTHORS' CONTRIBUTIONS}

IOO, OSC and AOB conceived and designed the study, OSC collected and analyzed samples with technical assistance from OOA and under the supervision of IOO and AOB. The statistical analysis was done by OSC with guidance from IOO and AOB. OSC and IOO drafted the manuscript, IOO, OSC and $\mathrm{AOB}$ revised the manuscript and all authors read and approved the final manuscript.

\section{REFERENCES}

[1]. FAO 2018. Fisheries Technical Papers-T142. The production of fish meal and oil. Fisheries Industries Division, Food and Agriculture Organization of the United Nations, Rome, Italy. http://www.fao.org/DOCREP/003/X6899E/X6899 E00.HTM

[2]. FAO 2018. Global trend of aquaculture

[3]. José AV, Sylvia P D, Julio AC, Magdalena de JU, María del CC, Ignacio O, María, EB Microbiological Analysis Of Tilapia And
Water In Aquaculture Farms From Sinaloa; Microbiological analysis of tilapia 2018; BIOtecnia XX (1).: 2026.doi: 10.18633/biotecnia.v20i1.525

[4]. Nelson, J. S. Fishes of the World, 4th edition. Hoboken, NJ: John Wiley and Sons. ISBN-10 : 0471250317; 624 pages; 2006.

[5]. Chapman FA. Culture ofhybrid tilapia: a reference profile. Circular 1051, Department of Fisheries andAquatic Sciences, Florida Cooperative Extension Service, Institute ofFood andAgricultural Sciences, University ofFlorida, 1992; pp.8

[6]. FAO 2016. The State of World Fisheries and Aquaculture 2016. Contributing to Food Security and Nutrition for All. Rome. 200 pp.

[7]. Robin, J, Cravedi, J., Hillenweck, A., Deshayes, C. and Vallod, D. "Off flavor characterization and origin in French trout farming". J.Aquac2006; 260: 128.doi:10.1016/j.aquaculture.05.058

[8]. Ayanda IO, Dedeke GA, Ekhator U I, Etiebet AK. Proximate Composition and Heavy Metal Analysis of Three Aquatic Foods in Makoko River, Lagos, Nigeria. J.Food Qual. 2018; 2362843; 6.doi:10.1155/2018/2362843

[9]. Norma H, Santos G. Animals as sources of food-borne pathogens: A review. Animal Nutrition 2018; 4(3); doi: 10.1016/j.aninu.2018.04.006

[10]. Ibrahim AR, Lawan FA, Bello HS, Musa AS,Ameh JA, Ambali AG. Occurrence and antimicrobial susceptibility profiles of Salmonella serovars from fish in Maiduguri, sub-Saharah, Nigeria. Egyp. J. Aquatic Res.2014; 405963; doi:10.1016/j.ejar.2014.01.003

[11]. Vasemägi A, Visse M,Kisand V. Effect of Environmental Factors and an Emerging Parasitic Disease on Gut Microbiome of Wild Salmonid Fish. of wild salmonid fish. MSphere2017;2(6):e0041817; doi: 10.1128/mSphere.00418-17.

[12]. Fernandes DV, Castro VS, Cunha-Neto A,Figueiredo E E. Salmonella spp. in the fish production chain: a review. Cienc. Rural, 2018; 48(8):1-11.Doi:10.1590/0103-8478cr20180141

[13]. Elhadi N, Aljeldah M, Aljindan. Microbiological contamination of imported frozen fish marketed in Eastern Province of Saudi Arabia. Int. Food Res. J 2016;23(6): 2723-2731.

[14]. Jarvis NA, O'Bryan CA, Dawoud TM, Park SH, Kwon YM, Crandall PG,Ricke SC. An Overview of Salmonella Thermal Destruction during Food Processing and Preparation. J.Food Con. 2016; 68, 280-290.doi:10.1016/j.foodcont.2016.04.006.

[15]. Farias MDCA, Freitas JDA..Qualidademicrobiológica de pescadobeneficiadoemindústriasparaenses. Revista do Instituto Adolfo Lutz 2008; 67:113-117; doi:10.1590/0103$8478 \mathrm{cr} 20180141$

[16]. Sant'ana A. Introduction to the Special Issue: Salmonella in foods: evolution, strategies and challenges. Food Res Int.2012; 45:451454;doi: 10.1016/j.foodres.2012.01.003.

[17]. Paudyal N, Anihouvi V, Hounhouigan D, Matsheka M, SekwatiMonang B, Amoa-Awua W, AtterA, Ackah N, Mbugua S, Asagbra A, Abdelgadir W, Nakavuma J, Jakobsen M,Fang W. Prevalence of foodborne pathogens in food from selected African countries - A meta-analysis. Int. J. $\quad$ Food Microbiol 2017; 249: 35-43; doi:10.1016/j.ijfoodmicro.2017.03.002

[18]. Cortés-Sánchez, A De J, Espinosa-Chaurand LD, Garza-Torres R, Diaz-Ramirez M, Ma. Salgado-Cruz De LP, Sánchez-Minutii, L, García-Barrientos R. Foodborne diseases, fish and the case of Aeromonas spp.. African J. Agric. Res. 2019; 14(11), 617-628; doi:10.5897/AJAR2019.13872

[19]. Centers for Disease Control and Prevention (CDC). Salmonella Infections Linked to Frozen Raw Tuna 2019. Available at: https://www.cdc.gov/salmonella/newport-04-19/index.html. Accessed on:04/06/2020

[20]. World Health Organization (WHO. Interventions for the control of non -typhoidal Salmonella spp. in beef and 729 pork: meeting report and systematic review 2019. Available at: https://apps.who.int/iris/bitstream/handle/10665/254893/97892412 10027_eng.pdf;jsessionid=64E4BD2BD2EC3ADD8E1BBBC6DF $\mathrm{D} 3 \mathrm{~B} 2 \overline{\mathrm{F}} 5$ ? sequence $=1$. Accessed on $04 / 06 / 2020$

[21]. Raufu IA, Lawan FA, Bello HS, Musa AS, Ameh JA, Ambali AG. Occurrence and antimicrobial susceptibility profiles 
of Salmonella serovars from fish in Maiduguri, sub-Saharah, Nigeria. Egypt. J. Aquatic Res. 2014; 40, 59-63. doi: 10.1016/j.ejar.2014.01.003

[22]. Nguyen DTA, Kanki M, Nguyen PD, Le HT, Ngo P T, Tran DNM,Le NH,Dang CV,Kawai T, Kawahara R, Yonogi B, Hirai Y, JinnaiM, Yamasaki S, Kumeda Y, Yamamoto Y. Prevalence, antibiotic resistance, and extended-spectrum and AmpC $\beta-$ lactamase productivity of Salmonella isolates from raw meat and seafood samples in Ho Chi Minh City, Vietnam. Int. J. Food Microbiol. 2016; 236, 115-122. doi: 10.1016/j.ijfoodmicro.2016.07.017

[23]. WHO. World Health Organization. 2014. Antimicrobial resistance: global report on surveillance. Publications of the World Health Organization are available on the WHO website (http://www.who.int) or can be purchased from WHO Press, World Health Organization, 20 Avenue Appia, 1211 Geneva 27, Switzerland. Available from: http://www.who.int/about/licensing/copyright_form/en/inde x.html $>$.

[24]. Cosby D, Nelson C, Mark H, Jeanna W, Richard B, Paula FC. Salmonella and antimicrobial resistance in broilers: A review. J.Appli Poultry Res. 2015; 24. doi:10.3382/japr/pfv038.

[25]. Crump J A, Heyderman RSA. Perspective on Invasive Salmonella Disease in Africa. Clinical Infectious Diseases 2015; 61(S4):S235-40.doi: 10.1093/cid/civ709.

[26]. Tiamiyu AM, Soladoye MO, Adegboyega TT,Adetona MO. Occurrence and Antibiotic Sensitivity of Bacterial Strains Isolated from Nile Tilapia, Oreochromis niloticus Obtained in Ibadan, Southwest Nigeria. J. Biosciences and Medicines 2015; 3, 1926.doi:10.4236/jbm.2015.35003

[27]. Adebayo-Tayo BC, Odu NN, Anyamele LM, Igwiloh NJPN,Okonko IO Microbial Quality of Frozen Fish Sold InUyo Metropolis. Nature and Science 2012;10(3): 71-77.

[28]. Danba EP, Bichi AH, Ishaku S, Ahmad Buba MK, Bingari UM, Barau SBW, Fidelis UF. Occurrence of pathogenic Bacteria associated with Clariasgariepinus in selected Fish farms of Kumbotso local Government area of Kano state, Nigeria. Bajopas2014; 7 (2).: 145-49. 46.doi: 10.4314/bajopas.v7i2.25

[29]. Shinkafi SA, Ukwaja VC. Bacteria Associated with Fresh Tilapia Fish (Oreochromis niloticus). Sold At Sokoto Central Market in Sokoto, Nigeria. Nigerian Journal of Basic and Applied Science 2010; 18(2): 217-221.doi: 10.4314/njbas.v18i2.64315

[30]. Seel SK, Kabir SML, Islam MA. Molecular detection and characterization of Escherichia coli isolated from raw milk sold in different markets of Bangladesh.Bangl. J. Vet. Med. (2016). 14 (2): 271-275.doi: 10.3329/bjvm.v14i2.31408

[31]. Fuhrimann S, Stalder M, Winkler MS, Charles B. NiwagabaCB,Babu M, Masaba G, Kabatereine NB, Halage AA, Schneeberger PHH, Utzinger J, Cissé G. Microbial and chemical contamination of water, sediment and soil in the Nakivubo wetland area in Kampala, Uganda. Environ Monit Assess2015; 187, 475.doi: 10.1007/s10661-015-4689
[32]. Adedeji OB,Tiamiyu AM, Emikpe BO. The Antibiotic Resistant Patterns of Bacterial Flora of Fish from Different Aquatic Environments from Ibadan, South-west Nigeria. Adv. Environ. Biol., 2011; 5(8): 2039-2047

[33]. Efuntoye, MO, Olurin KB,Jegede, GC. Bacterial Flora from Healthy Clariasgariepinus and their Antimicrobial Resistance Pattern. Advance Journal of Food Science and Technology 2012; 4(3): 121-125. 46.doi:10.1186/s41936-020-00168-w

[34]. Okpo NO, Abdullahi IO, Whong CMZ,Ameh JB.Occurrence and antibiogram of Staphylococcus aureus in dairy products consumed in parts of Kaduna State, Nigeria. Bayero Journal of Pure and Applied Sciences 2016; 9(2): $225 \quad-$ 229.doi:10.4314/bajopas.v9i2.39

[35]. Rafael B, Raquel Á, Christopher F, Carlos G, Rosa MR.Trypanosomatids topoisomerase re-visited. New structural findings and role in drug discovery. Int. J. Parasitology and Drugs Resistance; 2014; 4(3): 326-337.doi:10.1016/j.ijpddr.2014.07.006

[36]. Kikomeko H, Wamala SP,Mugimba KK. Antimicrobial resistance of Escherichia coli found in intestinal tract of Oreochromis niloticus. Uganda J. Agricultural Sc, 2016, 17 (2): 157 164.doi:10.4314/ujas.v17i2.3

[37]. Costanzo SD, Murby J,Bates J. Ecosystem response to antibiotics entering the aquatic environment. Marine Pollution Bulletin; 2005; 51(1).: 218-223. doi:10.1016/j.marpolbul.2004.10.038

[38]. Adedeji OB, Okerentugba PO, Innocent DE, Adiele HC,Okonko IO. Benefits, Public Health Hazards and Risks Associated with fish Consumption. NY. Sci. J. 2012; 5 (9):33-61.

[39]. Ibemenuga KN, Okeke T E. bacteriological quality of freshwater fish caught from two natural lakes in the rainforest region of South-Eastern Nigeria. Journal of Animal research international 2014; 11(2).: $1946-1952$

[40]. Clinical and Laboratory Standards Institute. Performance Standards for Antimicrobial Susceptibility Testing 2017; M02A12, M07-A10, and M11-A8. 27th Edn, 282.

[41]. ICMSF. Microorganisms in Foods, Sampling for Microbiological Analysis: Principles and Specific Applications 1986;2ndEdn, University of Toronto Press, Toronto.

[42]. ICMSF., 2005. Microorganisms in Foods, Sampling for Microbiological Analysis: Principles and Specific Applications. 2nd Edn, University of Toronto Press, Toronto

[43]. Robin, Joël; Cravedi, Jean-Pierre; Hillenweck, Anne; Deshayes, Cyrille; Vallod, Dominique (2006). "Off flavor characterization and origin in French trout farming". Aquaculture. 260: 128.

[44]. World Health Organization (WHO). WHO estimates of the global burden of foodborne diseases 2019. Available at: https://apps.who.int/iris/bitstream/handle/10665/199350/97892415 65165_eng.pdf?sequence $=1$. Accessed on : 04/04/2020

[45]. Levy SB. 2002. The 2000 Garrod Lecture. Factors impacting on the problem of antibiotic resistance. J. Antimicrob. Chemother. 49:25-30. doi:10.1093/jac/49.1.25 